\title{
Impact of Capacity Mobilization on Solid Waste Management A Case Study in Kundasale Pradeshiya Sabha
}

\author{
W.P.S. Perera, B.F.A. Basnayake and H.K.P.P. Kariyawasam \\ Center for Renewable Energy Sources (CRES) \\ Postgraduate Institute of Agriculture \\ University of Peradeniya \\ Peradeniya, Sri Lanka
}

\begin{abstract}
Capacity mobilization in solid waste management is defined as the mobilization of potential and existing resources of communities, organizations, institutions and local authorities effectively and efficiently for managing solid waste. The objective of this study was to assess the effect of implemented capacity mobilization programme on solid waste management in year 2007. This objective was achieved by measuring the approximate quantities of different kinds of waste disposed and by assessing the knowledge and application of $3 R$ system within identified 2 sample areas after a lapse of one year. Two sets of sample Groups were selected with 30 individual households with and without the participation for capacity mobilization programme in year 2007 from Kundasale Pradeshiya Sabha including 2 Grama Niladhari divisions Maharatenna and ManikhinnaEast. Sampling was done randomly from households along the two major waste collecting streets. Preliminary analysis showed that the general characteristics of these two Groups are more or less equal. Therefore, the only difference of these two groups with respect to solid waste disposal can be due to the capacity mobilization programme conducted in year 2007. The calculated waste discharge rate of the group that participated in the capacity mobilization programme is $1.86 \mathrm{~kg}$ / person-week while the other group produced 2.84 $\mathrm{kg} / \mathrm{person}$-week. There is a significant difference between two sample means of waste discharge rate between the two groups. Also, the group which was exposed to capacity mobilization programme showed relatively high rate of application of waste separation system in their own households and were well aware about impacts of burning of polythene. They had more positive ideas to improve solid waste management practices compared to the other group. Therefore, there is a positive impact of capacity mobilization programme on solid waste management in the studied area. Also, it is of utmost importance to undertake follow up procedures up to a reasonable time limit to keep the participants in the correct course of action until they naturally enter the environmentally safe waste disposal procedures.
\end{abstract}

\section{INTRODUCTION}

Solid waste is defined as non-liquid waste material arising from domestic, trade, commercial, industrial and agricultural activities as well as waste arising from the public sector (Anon., 2002). There are three classifications for solid wastes based on the source of origin, biodegradability and toxicity (Chereminoff, 2002). Improper disposal of solid waste has become a vital and critical issue in most of the areas of Sri Lanka. Unmanaged and unsafe solid waste dumping causes problems of health, sanitation and environmental degradation. Solid waste management (SWM) is one of the essential services that suffer 
most in such situations due to lack of financial resources, institutional weaknesses and public apathy towards solid waste management. In Sri Lanka, local government authorities (LAs) are primarily responsible for general waste management. Annually, LAs have to bear huge expenditure on SWM, and most of the problems faced are not technical issues but institutional ones. It is obvious that technology alone cannot solve these problems and improvement must be made through institutional and managerial capacity mobilization. The concept of capacity mobilization is introduced for effective use of resources in solid waste management. Capacity mobilization in SWM is defined as mobilization of potential and existing resources (mainly human and available funds) of communities, organizations, institutions and local authorities effectively and efficiently, for managing solid waste (Jagath et al., 2002).

Kundasale Pradeshiya Sabha (KPS) is one of the local authorities of twenty-two LAs in Kandy district. It covers the area of $85.8 \mathrm{~km}^{2}$ and the population is around 124,000. KPS includes two main cities of Digana and Manikhinna, and provides garbage collection service to the public of KPS area. Large amount of garbage is collected from two main cities, two hospitals, two bus stands, three main roads and six sub roads. Daily garbage collection is done only on main roads, and from the other areas it is collected only one to two times per week. The extent of available garbage disposal site is two hectares and belongs to KPS and Mahaweli Development Authority. The main objective of this study was to assess the effect of implemented Capacity Mobilization Programme (CMP) on solid waste management launched in year 2007. This objective was achieved by measuring the approximate quantities of different kinds of waste disposed and by assessing the knowledge and application of 3R (Reduce, Reuse and Recycle) system within the identified 2 sample areas after a lapse of one year.

\section{MATERIALS AND METHODS}

This study was carried out using two sets of sample Groups; one Group had participated in the CMP and the other Group had not participated in the program in 2007. The original CMP had been organized by the Environmental Resource Center at Kundasale Pradeshiya Sabha and conducted for 2 weeks within the selected area with five trained teams. The selected households (450) had been visited, spent 30-45 minutes for discussion, instructions and demonstrations on solid waste management.

\section{Study and sample areas}

The study area was Kundasale Pradeshiya Shaba and the sample area included 02 Grama Niladhari (GN) divisions, Maharatenna and Manikhinna-East. The sampling and evaluation was carried out randomly on 30 households each, along the two major waste collecting streets. The sample Groups who participated and did not participate are named as Group 01 and Group 02 respectively.

\section{Data collection and analysis}

The primary data was collected by conducting a survey using a questionnaire and by interviewing households in the study areas (Gunatilake, 2003). It was focused on the rate of waste generation at present, knowledge on SWM (waste separation at household level, application of 3R system), previous awareness programs and training programs participated, educational, social and economical background of SWM process and 
suggestions to improve SWM system. The secondary data was collected from both published and unpublished sources (DMSWSL, 2006). The data obtained from the field was analyzed in a database, which was created using SPSS and Microsoft Excel. Tables and graphs are used to present quantitative and qualitative data in descriptive manner (Steel and Torrie, 1960).

\section{RESULTS AND DISCUSSION}

The results are presented under three main phases. First is the assessment of general information of two sample Groups such as composition of family structures, income and employment status, assets and services in reference to mass media. According to the results, the general conditions are similar in two sample Groups. Therefore, it was possible to proceed with the analysis of next two phases. The second phase was the assessment of solid waste discharge by the two-sample Groups. Waste discharge rate was calculated and hypothesis was tested to find out the impact of CMP. In the final stage, existing solid waste management process was assessed considering the application of $3 \mathrm{R}$ system and comparing the knowledge between the two sample groups.

\section{Assessment of general information}

General composition

More than $85 \%$ were only households but some included small-scale commercial places, attached to their houses as percentage of $13.33 \%$ and $3.33 \%$ in Group 01 and 02, respectively. The average land area possessed by Group 01 and 02 are 414.56 and 448.57 $\mathrm{m}^{2}$ respectively. This clearly shows that the residents do not have enough space to dispose their own waste at present and it will be more restricted in the future (Table 1).

\section{Table 1. General information of sample groups}

\begin{tabular}{|c|c|c|c|c|}
\hline \multirow{2}{*}{ Description } & \multicolumn{2}{|c|}{ Group 01} & \multicolumn{2}{|c|}{ Group 02} \\
\hline & Quantity (No.) & Quantity (\%) & Quantity (No.) & Quantity (\%) \\
\hline Domestic \& commercial & 4 & 13.33 & 1 & 3.33 \\
\hline Domestic & 26 & 86.67 & 29 & 92.67 \\
\hline Average land area $\left(\mathrm{m}^{2}\right)$ & 414.56 & & 448.57 & \\
\hline $\begin{array}{l}\text { Participation for CMP in } \\
2007\end{array}$ & 30 & 100 & 0 & 0 \\
\hline $\begin{array}{l}\text { Participation for other } \\
\text { programme }\end{array}$ & 2 & 6.66 & 1 & 3.33 \\
\hline Male & 60 & 43.79 & 37 & 32.17 \\
\hline Female & 77 & 56.21 & 78 & 67.82 \\
\hline Total & 137 & 100 & 115 & 100 \\
\hline $\begin{array}{l}\text { Average family size } \\
\text { (Individuals) }\end{array}$ & 4.56 & & 3.83 & \\
\hline $\begin{array}{l}\text { Average family income } \\
\text { Rs/ month }\end{array}$ & 38,933 & & 34,667 & \\
\hline
\end{tabular}


Higher female population was observed in both Groups. Average family size and average family income were more or less equal. The family structure according to age limit also distinguished that the composition is almost identical in both Groups.

\section{Employment profile}

According to the present employment, $33.57 \%$ and $41.73 \%$ of the total population is employed in Group 01 and 02 respectively. From those employees, $69.57 \%$ and $58.33 \%$ are occupied in their own business or in the agricultural sector in Group 01 and 02, respectively. Average family income was recorded as Rs. 38,933 and Rs. 34,667 per month in Group 01 and Group 02, respectively (Table 2).

Table 2. Employment profile of two Groups

\begin{tabular}{|c|c|c|c|c|}
\hline \multirow{2}{*}{ Description } & \multicolumn{2}{|c|}{ Group 01} & \multicolumn{2}{|c|}{ Group 02} \\
\hline & Quantity (No.) & Quantity (\%) & Quantity (No.) & Quantity (\%) \\
\hline Employed individuals & 46 & 33.57 & 48 & 41.73 \\
\hline \multicolumn{5}{|c|}{ Employment compositions } \\
\hline Government sector & 4 & 8.69 & 2 & 4.16 \\
\hline Private sector & 2 & 4.35 & 11 & 22.93 \\
\hline $\begin{array}{l}\text { Own business/ self } \\
\text { employed/ farmer }\end{array}$ & 32 & 69.57 & 28 & 58.33 \\
\hline Retired & 8 & 17.39 & 7 & 14.58 \\
\hline
\end{tabular}

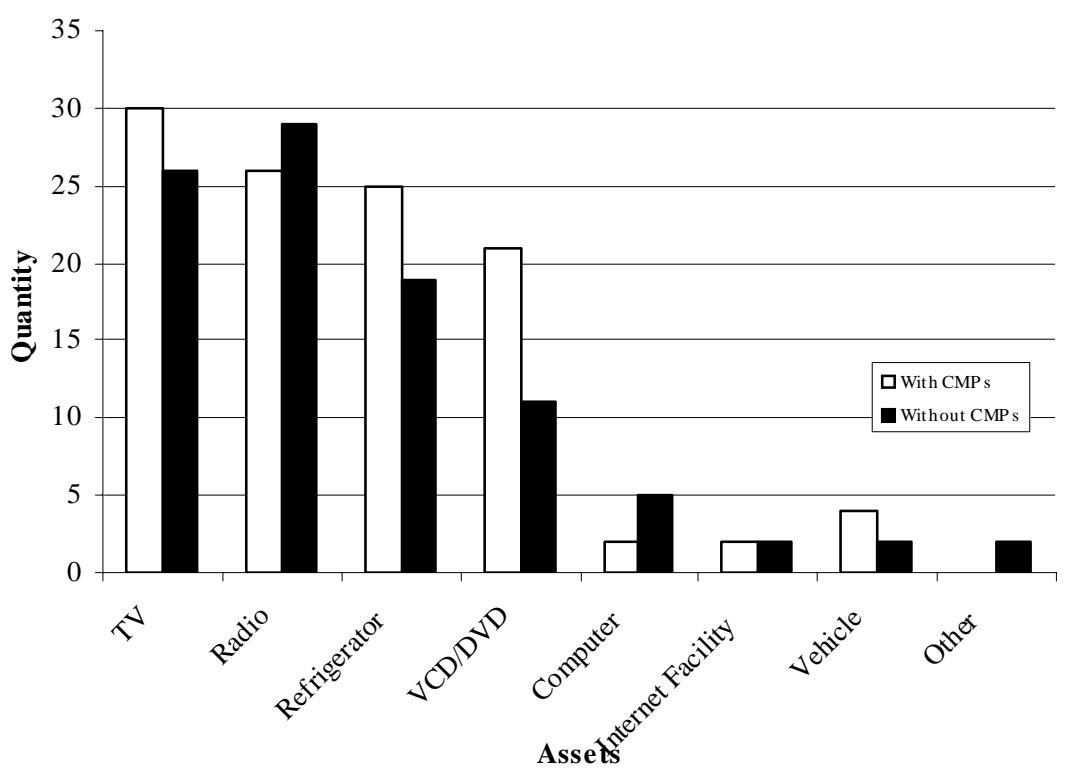

Fig. 1: Available assets of two Groups 
Perera et al.

\section{Available assets and services with reference to mass media}

Available assets in both Groups were more or less similar (Fig. 1). The average television watching time of 2.0 and 2.2 hours/ family.day was recorded in Groups 01 and 02 respectively. Average listening time and number of newspapers read by a person per day are also more or less equal and this leads to the conclusion that impact from mass media is comparable in both Groups.

\section{Assessment of waste disposal rate}

The rate of waste disposal was analyzed after eliminating noticeable outliers from the range over three times the standard deviation. The distributions were assumed normal and twosample $t$ test was performed to determine difference of means. The mean weight of discharged organic waste by the Group 01 was $1.621 \mathrm{~kg} /$ person.week, while it was 2.35 $\mathrm{kg} /$ person.week in Group 02 (Tables 3,4 and 5). The mean weight of discharged plastic and polythene by the Group $01(0.101 \mathrm{~kg} /$ person.week $)$ was more or less half of the discharge from Group $02(0.218 \mathrm{~kg} /$ person.week $)$.

Table 3. Rate of waste discharged by waste category in Group 01

\begin{tabular}{lcccc}
\hline \multicolumn{5}{c}{ Group 01 (With CMP) } \\
Dis. & Organic & $\begin{array}{c}\text { Plastic/ } \\
\text { Polythene }\end{array}$ & Other & Total \\
\hline Mean* & 1.6213 & 0.1007 & 0.2205 & 1.8584 \\
Max* & 3.40 & 0.50 & 0.75 & 3.80 \\
Min* & 0.25 & 0.00 & 0.10 & 0.38 \\
SD & 0.6695 & 0.1096 & 0.1597 & 0.8242 \\
Var. & 0.4482 & 0.0120 & 0.0255 & 0.6793 \\
\hline
\end{tabular}

* The units of mean, maximum and minimum are expressed in $\mathrm{kg} /$ person. week

Table 4. Rate of waste discharged by waste category in Group 02

\begin{tabular}{lllll}
\hline \multicolumn{5}{c}{ Group 02 (Without CMP) } \\
Dis. & Organic & $\begin{array}{l}\text { Plastic/ } \\
\text { Polythene }\end{array}$ & Other & Total \\
\hline Mean* & 2.3444 & 0.2168 & 0.1981 & 2.8427 \\
Max* & 6.50 & 1.10 & 0.50 & 7.50 \\
Min* & 0.75 & 0.00 & 0.00 & 0.88 \\
SD & 2.9685 & 0.5827 & 0.2518 & 3.4023 \\
Var. & 8.8122 & 0.3395 & 0.0634 & 11.5755 \\
\hline
\end{tabular}

* The units of mean, maximum and minimum are expressed in $\mathrm{kg} /$ person. week

The overall rate of waste discharged by Groups 01 and 02 were 1.859 and $2.84 \mathrm{~kg} /$ person.week, respectively. These mean values are significantly different and the difference could be due to the positive impact made by CMP, influencing organic waste composting in own premises and also reduced use of plastic and polythene. However, in the case of 
practicing domestic composting, 36.76\% households were using domestic compost pits or Jeewakotu by Group 01 while the other Group was $16.67 \%$ (Table 6). CMP has shown importance to improve domestic composting. It has been successful to some extent, and further improvement is required.

All the other waste such as cardboard, metal, glass were pooled under the category of other waste, because these represent in less quantities compared to the other two major categories. The mean amount of other waste discharged by the Groups 01 and 02 were 0.222 and $0.199 \mathrm{~kg} /$ person.week respectively and the means are not significantly different. The CMP conducted may not have had a positive impact on reducing the rate of discharge of other waste in the given community or because of the broadens of the category; it is not possible to see the real effect of it. Therefore, to make CMPs more effective further improvements should be made in planning CMP.

Table 5. Summary of the results of the t-test on waste discharge rate

\begin{tabular}{llcccccccc}
\hline \multirow{2}{*}{ Rank } & \multirow{2}{*}{ Category } & \multicolumn{2}{c}{ With CMPs } & \multicolumn{2}{c}{ Without CMPs } & \multirow{2}{*}{ T-Value } & \multirow{2}{*}{ P-Value } & \multirow{2}{*}{ Result } \\
\cline { 3 - 7 } & & Mean & SD & Mean & SD & & & \\
\hline 1 & Organic & 1.621 & 0.67 & 2.35 & 1.39 & 2.56 & 0.014 & S \\
2 & Plastic/ & 0.101 & 0.110 & 0.218 & 0.272 & 2.19 & 0.034 & $\mathrm{~S}$ \\
& polythene & 0.101 & & & & & & \\
3 & Other & 0.222 & 0.159 & 0.1997 & 0.0966 & -0.64 & 0.525 & $\mathrm{NS}$ \\
4 & Total & 1.859 & 0.824 & 2.84 & 1.78 & 2.74 & 0.009 & $\mathrm{~S}$ \\
\hline
\end{tabular}

S- significant, NS- Not significant

\section{Assessment of community participation in strengthening SWM process}

Point source separation is one of the key activities in SWM process and it is applied by $50 \%$ of households in Group 01 while it is $16.67 \%$ in the other Group. Point source separation is the most effective step of $3 \mathrm{R}$ system (Table 6). It is useful in improving waste collection procedures.

Kundasale Pradeshiya Shaba uses enclosed tractor-trailers with 03 compartments to transport waste separately as organic, paper, hard plastic and polythene. The percentage of polythene burning was 5\% in Group 01 and $50 \%$ in Group 02 . Also $70 \%$ of households were habitually burning polythene. However, Group 01 does not burn polythene $(2.67 \%)$ frequently. This result is also supportive of the positive impact made by the CMP on proper waste management in KPS.

\section{Assessment of the effort made by LA in SWM process}

The participant's perceptions on the problems associated with waste management were assessed. More than $40 \%$ of households believed that irregular collection of waste by the LA is the most acute problem. In certain instances, LA had failed to maintain regular collection process. Group 01 expects to receive more awareness and training than the other Group. In addition, a point source separation is much more appreciated by Group 01 and expects to perform in a more effective manner than Group 02. 
Table 6. Evaluation of the solid waste management practices

\begin{tabular}{lcccc}
\hline & \multicolumn{2}{c}{ Group 01 } & \multicolumn{2}{c}{ Group 02 } \\
Description & $\begin{array}{c}\text { Quantity } \\
\text { (No.) }\end{array}$ & $\begin{array}{c}\text { Quantity } \\
(\%)\end{array}$ & $\begin{array}{c}\text { Quantity } \\
\text { (No.) }\end{array}$ & $\begin{array}{c}\text { Quantity } \\
(\%)\end{array}$ \\
\hline Application of waste sorting & 15 & 50 & 5 & 16.67 \\
system (Point source separation) & & 30 & 3 & 10 \\
Bins from PS (Rs 300/ bin) & 9 & 83.33 & 14 & 46 \\
Reuse of polythene, paper \& & 25 & 2.67 & 21 & 70 \\
cardboards & 2 & & & \\
Habitual practice of polythene & 10 & 33.33 & 3 & 10 \\
burning & 13 & 63.33 & 10 & 33.33 \\
Access to dumping yard in their & & & & \\
own PS & 12 & 40 & 15 & 50 \\
Satisfaction on services of PS & 16 & 53.3 & 11 & 36.7 \\
Disposal of solid waste & 2 & 6.7 & 4 & 13.3 \\
$\begin{array}{l}\text { Direct dumping on own land } \\
\text { Handing over the waste to PS }\end{array}$ & 7 & 23.33 & 3 & 10 \\
Burning & 4 & 13.33 & 2 & 6.67 \\
$\begin{array}{l}\text { Domestic compost pit } \\
\text { Jeewakotu }\end{array}$ & & & & \\
\hline
\end{tabular}

Local authorities are the responsible institutions to handle solid waste in Sri Lanka. Thus, regarding the best institution to handle solid waste, Group 01 has more reliance on the services provided by the LAs (Table 7). The Group, which did not receive CMP, seems to have more faith on private sector (Table 8). CMP has provided a good passage for LAs to create a good relationship with the community, which indirectly helps in reducing the annual expenditure on waste management made by LAs.

Table 7. View on the present SWM practices in KPS

\begin{tabular}{lcccc}
\hline Description & \multicolumn{2}{c}{ Group 01 } & \multicolumn{2}{c}{ Group 01 } \\
& $\begin{array}{c}\text { Quantity } \\
\text { (No.) }\end{array}$ & $\begin{array}{c}\text { Quantity } \\
(\mathbf{\%})\end{array}$ & $\begin{array}{c}\text { Quantity } \\
\text { (No.) }\end{array}$ & $\begin{array}{c}\text { Quantity } \\
(\%)\end{array}$ \\
\hline $\begin{array}{l}\text { Collection is irregular } \\
\begin{array}{l}\text { Collectors do not come to each and } \\
\text { every household }\end{array}\end{array}$ & 12 & 40 & 15 & 50 \\
$\begin{array}{l}\text { Have to bribe to have waste } \\
\text { collected }\end{array}$ & 4 & 13.33 & 9 & 30 \\
$\begin{array}{l}\text { Improper participation of PS } \\
\text { No response }\end{array}$ & 2 & 26.66 & 1 & 3.33 \\
\hline
\end{tabular}


Table 8. Perceptions on solid waste management

\begin{tabular}{lcccc}
\hline \multirow{2}{*}{ Description } & \multicolumn{2}{c}{ Group 01 } & \multicolumn{2}{c}{ Group 02 } \\
& $\begin{array}{c}\text { Quantity } \\
\text { (No.) }\end{array}$ & Quantity & Quantity & Quantity \\
& & (No.) & $(\%)$ \\
\hline
\end{tabular}

Agree to bear the full cost of SWM

1. Strongly disagree

2. Disagree

3. Neutral

4. Agree

5. Strongly agree

6. No Response
0

$2 \quad 6.67$

$5 \quad 16.67$

16

3

4
$0 \quad 6$

6

4

53.33

10

13.33
20

46.67

13.33

0

0

20

Best Institute to handle SW

\begin{tabular}{lcccc} 
1.PS & 14 & 46.67 & 10 & 33.33 \\
2.Private Sector & 9 & 30 & 15 & 50 \\
3.Both & 7 & 23.33 & 3 & 10 \\
4. No Response & 0 & 0 & 2 & 6.67 \\
\hline
\end{tabular}

However, the gap to be filled at this stage is the collaboration of the LAs and other relevant government organizations in launching proper CMPs and monitoring programmes. Nevertheless, the observation throughout the study is that, there was minimum involvement of the LA in many aspects of general SWM. Somehow, LAs must understand the real longterm benefits of understanding the correct waste management procedures by public. Otherwise, any of the CMP carried out will not be effective in the long run. Allocation of adequate expenditure as well as human resources of LAs for regular waste collection and management is of utmost importance. Therefore, LAs should pay more attention on improvement of the SWM process.

\section{CONCLUSIONS}

The general characteristics (income, family structure, employment, assets, and services with reference to mass media) of the two selected Groups are more or less equal. However, there is a significant difference between two sample means of waste discharge rate. Therefore, the differences in solid waste disposal of these two groups could be due to the influence made by the CMPs conducted in 2007. The Group, which has received CMP, has relatively high rate of application of waste separation system at their own households and well aware of the consequences of burning polythene and they also have more positive ideas to improve SWM systems compared to the other group. The percentage satisfaction on SWM process launched by KPS in the Group, which has received CMP is comparatively higher than the other, which means the KPS is providing better service for the Group, which has received CMP than the others. If the public actively participate in proper solid waste disposal, local authorities will be the real beneficiaries in many aspects. Local Authorities must pay their fullest attention in guiding the community as well as training the collecting crew for better SWM process. In addition, the improvement of infrastructure is essential at every step of SWM. The observations made throughout implies the importance of undertaking follow up procedure for a reasonable period after a CMP, to keep the participants in the correct course of action until they naturally enter the environmentally safe waste disposal procedures. 


\section{ACKNOWLEDGMENT}

The authors are grateful to the Solid Waste Management Research Unit, Department of Agricultural Engineering, Faculty of Agriculture, University of Peradeniya for technical support given for the study. A Special thank to Kundasale Pradeshiya Shaba and sample households for their support to perform this study.

\section{REFERENCES}

Anonymous (2002). National Strategy for Sold Waste Management. Ministry of Environmental and Natural Resources, Sri Lanka.

Cheremisinoff, N.P. (2002). Handbook of Solid Waste Management and Waste Minimization Technologies. Butterworth and Heinemann, USA.

DMSWSL, Database of Municipal Solid Waste in Sri Lanka, (2006). Ministry of Environmental and Natural Resources, Sri Lanka.

Gunatilake, H.M. (2003). Environmental Valuation: Theory and Applications. Postgraduate Institute of Agriculture, University of Peradeniya, Sri Lanka.

Jagath, N.K.M., Basnayake, B.F.A. and Nirosha, K. (2002). Development of an integrated solid waste management system for three local authorities in Sri Lanka through capacity mobilization. Tropic.l Agric.1 Rese. 14: 280-291.

Steel.G.D.R. and Torrie H.J. (1960). Principles and Procedures of Statistics, Hill book Company, Mcgraw. 